\title{
CHAMPS ELYSÉES
}

Horácio Costa ${ }^{1}$

These days which, like yourself,

Seem empty and effaced

Have avid roots that delve

To work deep in the waste.

James Merrill, Late Settings

Estou eivado de auto-piedade.

Aquele bolsão lipídico do sovaco,

lembra-se?, que já se fazia presente

na Impressão da Viagem

de 1980

não fez senão aumentar.

O pé esquerdo com freqüência incha.

Não disse inca, Manco Capac,

Tupac Amaru: disse incha.

"Gonfle", em francês.

Não refresca nada saber o verbo

na língua de Valéry. O pé esquerdo

continua inchado.

Era de tarde e entramos no casarão

de D. Inocência Prates

na Rua Guaianases. Aí aprendi

que o Trianon existira antes do MASP

\footnotetext{
1 Poeta, tradutor, professor e ensaísta. Publicou, entre outros livros, 28 Poemas / 6 contos (1981), Satori (1989), O Livro dos Fracta (1990) e Quadragésimo (1999). Leciona Literatura Portuguesa na Universidade de São Paulo (USP).
} 


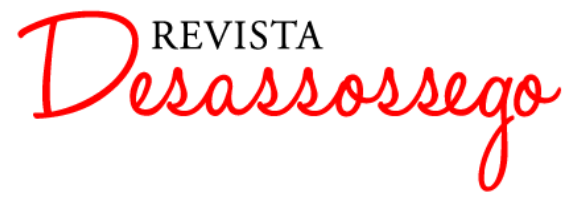

e que os bailes a fantasia no carnaval

pegavam fogo, em plena Paulista.

D. Inocência nos recebeu tão

humildemente. Frágil, mal vestida,

mas no salão tinha um par de dunquerques

cobertas de mármore, bem Napoléon III

e poucas antiguidades mais.

Em cinco minutos, narrou

o que de importante havia

em sua memória:

há 40 falava de um mundo

de havia 50 anos.

Hoje passei frente à que fora sua casa

na Rua Guaianases. Com o pé esquerdo

inchado. O casarão de Dino Bueno

continua lá e tantos outros

preservados pela acertada decisão corporativa

da Grande Empresa de Seguros.

A memória pode, sim,

ser comprada, e negociada,

e, claro, vendida,

para lá dos metros lineares

das lombadas de livros falsos

que adornem bibliotecas

dos CEOs das ditas

Grandes Empresas de Seguros.

Todos tão de si mesmos inseguros, tais CEOs? Já não comprarão lombadas

em marroquim, às vezes sem sequer

incomodarem-se por não terem 
títulos os volumes...

Venceslau Pietro Pietra foi

devidamente, pós-modernamente

substituído por executivos que sabem

que em cada poema há uma gota de sangue

e que muito sofrimento é necessário

pour un air de guitarre...

Já não é tão caricata

São Paulo! o gosto, o dito

bom-gosto, imiscuiu-se

pela retina adentro dos detentores

do dinheiro... Não compram

livros por metro linear:

compram casarões cenográficos

e os enchem de móveis do melhor design

ao pé de prédios de construção recente

que por sua vez enchem de operadoras

de atendimento telefônico à distância.

Quem duvida e de bilioso me indigita,

que leia L'Esthétisation du Monde:

vivre à l'âge du capitalisme artiste

de Lipovetsky, chez Gallimard.

Ponto,

não final.

E sempre terá sido assim?

Na Suméria, em Paris?

Será este o natural

caminho da cultura?

D. Inocência Prates, que nome, 
mamma mia, deve ter morrido

há muito e haver sido enterrada

(onde?) talvez pelos seus locatários

finais. Havia gatos.

Muito à la romaine havia gatos.

Claro que nunca mais os vi.

Estas são as memórias urbanas

que compartilho com o improvável

deste texto, leitor.

Sim, felinos: subidos nas dunquerques,

detrás das girandoles de Sèvres capengas

nas quais faltavam os pingentes de Baccarat

e cuja estrutura de ormolu

encontrava-se oxidada ou suja.

Olhavam-nos com a estudada compaixão

dos gatos, sem simpatia mas com beleza.

Assim foi.

Hoje há nuvens baixas:

as mesmas que terão visto sobre estes campos

ditos elíseos, les Champs Elysées de São Paulo,

o parvenu João Ramalho

e a sua índia Bartira?

O patrimônio histórico de São Paulo

encontra-se em boas mãos:

em porto seguro.

Mas a memória da memória

é ainda, por hoje, minha.

Cai a noite -nuvens bem bem

baixas- sobre a extensa mole 
urbanizada.

Como uma aquarela.

Quem a comprará?

Quem dá mais?

Este poema.

Et mon pied gauche,

biensûr, est encore gonflé.

Osasco, 13-22.I.14, na comemoração do $460^{\circ}$ aniversário de São Paulo 